\title{
Ethical Issues in Public Service
}

\author{
Adebayo Adeyinka O.
}

\begin{abstract}
The issue of ethics is beginning to gain ground in public Organization. Ethics are Standards and rules that are meant to be guiding principles for any institution such as public, private and Governmental. This research work examines the ethical issues in public services sectors in Nigeria. This paper is concerned with unethical behaviours in the public service among the public servants in Nigeria. Adopting the historical and literature review methods, this paper examines the historical antecedents of Civil Service in Nigeria; and reveals some specific unethical behaviour among the career Civil Service System proposed which include; Searching and Tracing of files and other documents, Gratification for service render, Deliberate Deception, Sale of Information or Espionage, Unlawful Conduct. All these come under the umbrella of corruption and indiscipline. The paper recommended some possible solutions that improve the Ethical standard in the public service.
\end{abstract}

Index Terms-Ethics issues, standards and rules, public services sectors, Nigeria.

\section{INTRODUCTION}

This article begins by revisiting the Ethical issues in public services in Nigeria [1]

The issue of Ethics is beginning to gain ground in public Organization. [2] In Nigeria, the public service sector is experiencing a myriad of problems ranging from lack of Indiscipline among the Civil Service workers, misappropriation of Public funds, laziness at work, corrupt practices and their cold and non-challant attitude towards their job and colleagues and moral values of the community [3].

In the words of Appleby [1952:7]. [4] He is of the view that "Moral performance begins in individual self -discipline on the part of officials, involving all that is meant by the word "Character". But this is not enough. Moral performance also requires a systematic process which supports individual group judgment enriched by contributions from person variously equipped and concerned and differentiation in responsibilities to each other and to a whole public responsibility. The official, individually and organizationally, must be concerned to be beyond simple honesty to a devoted guardianship of the continuity reality of an ethical behavior and environment. Ethics are standards and rules that are meant to be guiding principles for any institution such as public institutions. With ethics in place there is every likelihood that every organization will want to stand by it with the assurance that a negation of ethical rules and

Manuscript received August 15, 2013; revised October 17, 2013.

Adebayo Adeyinka O. is with the Social Science and Entrepreneurial Studies, Department of Public Administration, Lead City University, Toll Gate Area. P. O. Box. 30678, Secretariat, Ibadan, Oyo state, Nigeria (e-mail: adebayoadeyinka20@yahoo.com). standard shall be made to face full wrath of the law.

To appropriately discuss the focus of the article as listed above, this research work is divided into five segments. The first is the introduction, the second leg of the paper discusses the historical antecedents of Civil Service in Nigeria; the third takes a revelation of the unethical behaviours among public servants and the fourth examines the recommendations for the unethical behaviours. The fifth section is the conclusion of the article which is accompany by the references.

\section{HistoriCAl ANTECEDENTS OF CIVIL SERVICE IN NIGERIA}

It is now time to discuss the Nigeria Civil Service in concrete terms. To do this effectively, it is important that we have the idea of how it evolved and grown, through reform initiatives and practical policies. The Nigeria Civil Service, from which the present Federal Civil Service emerged, has an Origin which cannot be extricated from Whitehall-The British Government [5].

The origin of Nigeria Civil Service was traced to 1857, the year of the British Government's Conquest and annexation of Lagos, thereby proclaiming it a colony, and 'a rudimentary Civil Service' was there upon established [Olusanya, 1973] [2].

The formal establishment of a truly Nigerian Civil Service was in 1954. [Adamolekun, 1989:41] [2] until then the country was governed by officers of an administrative entity. In 1948, the Nigeria component of the colonial service was formally constituted into a distinct unit and its management was entrusted to a Civil Service Commissioner in the central Secretariat in Lagos. The Colonial Civil Service placed the Governor-General at the apex of the bureaucracy, and defined his duties and other spheres of influence.

By 1949, the centralized Public Service imposed on Nigeria in 1914 was already under serious stress. One destabilizing pressure was the growing centralization of industrial union Organizations and the disarming impact of the first nationwide industrial action of 1945. In other to halt the hold of this action of the unions, the Home Office in London saw the need compelling for a decentralization policy, the need to appoint Nigerians to posts in Government Service at the time.

In May 1948, a commission of inquiry was set up chaired by Mr. Hugh Foot, the then Chief Secretary of the Government to see to the policy to be administrated in appointing Nigerian to posts in Government Service. The commission established a decentralized framework for the Civil Service which was done through the birth of Regional Public Service Board and the Central Public Service Board, the precursor of the present Federal Civil Service Commission and State Service Commission [5]. 
The aim of this historical glance is to understand that Public Service Commissions are divided into the Federal Civil Service Commission, those working at the Federal Parastatals and the State Civil Service Commission; those working with the Stet Government. The birth of both Federal and State Civil Service Commissions and that length of Service is not as important as place of Service.

\section{UNETHICAL BEHAVIOURS}

However, it is worthy of note at this juncture that ethical issues have forced various governments to Introduce one form of Legislation to curb this monster. Ethical problems have become cankerworms that are eating deep into the bone marrows of both the Federal and the State Public Service Commissions in Nigeria. It is cancerous that spreads wantonly into every nooks and crannies of our Public Sectors. This is endemic among Public Servants. There are some unethical behaviors usually and often demonstrated among the public servants, among which are:

\section{A. Corruption}

I crave your indulgence to paint a portrait of the average Public Servant in the eye of the Society, in other to put the issue in its proper perspective conceptually;

$\mathrm{He}$ is employed in the ministry, department or agency of Government.

His grade, level and emoluments are graduated to reflect his educational qualifications.

Mostly he is not adequately remunerated since productivity is not a determining factor but Physical presence [6], [7].

$\mathrm{He}$ is entitling to both pension and gratuity on disengagement. Chuks (2012) [8].

A Public servant wants to measure up financially with his peers, age mates or school mates in the private sector. In essence he will work, retire and probably pass on, a poor man if he does not engage in corrupt activities while in service, whether covertly or overtly, depending on his rank, place of work and personal disposition. So, how does the average public servant survive the perennial pangs of abject poverty and spartanship? There is no doubt that bribery and corruption constitutes his stock -in- trade in various governmental units, especially at the lower and middle rungs of the service ladder [6].

Searching and Tracing of files and other documents

The Public servants get money from contractors and affected or interested parties for searching, tracing and follow-up of files and other documents that require the boss attention. A file can also suddenly develop wings and get missing if the expectations have not been met.

\section{1) Deliberate deception}

Deliberate deception in the work place includes taking credit for work done by someone else, calling in sick in order to go to the beach, or go partying, sabotaging the work of another person and, commercial runs at office hours with their personal cars when they are supposed to be at their desk attending to work as they appear, helping each other to sign the attendance $\log$.

\section{2) Sale of information or espionage}

Recently, the breaking of the terrorist group called Boko Haram in Nigeria into important and high places and offices like Army Barracks, and Police Stations in Abuja happened because of the sale of confidential information to this sects. The prison break in Kaduna, Sokoto and Kano was as a result of sold information by one of the public Servant. Recently eighteen soldiers appeared before a General Court Martial in Jos, Plateau State for aiding members of the fundamentalist Islamic sect, Boko Haram [9], [10].

\section{3) Gratification for services render}

An average Public Servant does not run an errand for free. No free launch in free town. They are of the nation that if I scratch your back, you must scratch mine too. They are eager to run an errand for you when you gratify and grease their palm.

In the light of the above discussion, the consequent decay of this unethical behaviour is being felt in the economy and social development of Nigeria. The damages the unethical problems had caused and are still causing can not be over-emphasized. This has brought about a retard growth in the social, economy and political area of the country.

\section{4) Unlawful conduct}

Padding an expense account with non -business expenses, raiding the supply cabinet to take home pens and note books and passing around unregistered or counterfeit software are examples of unlawful conduct. Hawking of wares and bodies which is predominant among female workers, who have turned their various offices into boutique. Those who cannot sell their bodies. The person who does all those risks losing his / her job.

\section{RECOMMENDATIONS}

According to Ogundele, Hassan and Adebakin (2007) [11], they are of the opinion that the promotion of ethical behaviour should take place in private organizations and all arms of government. There is an assertion that when nations, societies and other forms of organization, lose their sense of purpose and significance, then confusion, frustration, discouragement, corporate suicide, set in.

There are approaches suggested for promoting ethical behaviors:

\section{- Sanctions and punishments}

Impositions of heavy punishment on both individuals and organizations that breach business and societal ethics. The sanction must be heavy and prompt so as to serve as a deterrent to other offenders. If offenders are not punished, it tends to encourage other people who have potentials in crime committing. Strict sanction could be sufficient to discourage and curb unethical behaviour and make people obey instructions, customs or laws. Strict sanctions was exemplified during the Buhari/Idiagbon regime 1983-1985 in Nigeria, people were fearful of breaking laws, rules, regulations, e.t.c. that were designed for the good of all [1].

- Moral campaign

This method helps in inaugurating massive propaganda and campaign calling for disciplined behaviour and practices 
of moral values among public sectors. It is a moral evangelism of what is currently in place. This deadly disease of moral decadence should be addressed in public, private and governmental organizations [1].

The dangers inherent in perpetration of unethical conducts should be emphasized.

- Reward of outstanding ethical behaviour

In a situation or instances when an individual display an outstanding act of discipline behaviour such behaviour should be rewarded in status, cash and kind [1].

- Enlightenment

Massive education, training and development in schools, colleges and universities. Ethics should be made a compulsory subject cutting across all the various disciplines. As we all know education is the bedrock of all development of any society, education kills the blight of diseases, ignorance, superstitions, poverty and fear.

- Revival of culture of excellence

Values, Ethics and Cultures should be restored for instance; Africa had a robust excellence culture which modernization and civilization had robbed off their social fabric.

- Professional development of ethical codes

To restore and gain sanity and to earn respectability from outside world and prospective foreign investors, private, public and governmental organizations need to fashion out codes of ethics. It is to be noted that professional bodies, e.g. medicine, engineering, law, e.t.c. have ethical codes of conduct. A serious problem requires an equally serious solution [3].

- Religiosity

This is the application of doctrines enshrined in a particular religion [12] as the only permissible framework for ascertainment of right and wrong [13].

\section{CONCLUSION}

Attention has been drawn in this research work to the modest results achieved through the efforts aimed at arresting the decay and collapse of the ethical behaviours in the Civil Service systems among the Public servants. The central message of this article is the disgusting menace of unethical behaviour among public servants in the Public sector and the need for the country to embark on implementing some of the proposed remedial measures and a segment or department in the government or Public sector to act as a watch dog on both the Federal Civil Service Commission and the State Civil Service Commission to bring to book and justice the breakers of the ethics meant to regulate and guide the commissions.

\section{REFERENCES}

[1] O. J. K. Ogundele, Comparative Management and Administration, $2^{\text {nd }}$ ed., Palmgrove, Lagos Concept Publication Limited, 2010, pp. 515, 524, 526-531.

[2] A. O. Akinyemi, "Effective business training and practice: The Ethical Side," in Adeseye et al., [Edition], Polytechnic Education in Nigeria: Problems and Prospects, Lagos, 2002, Bolufemi Enterprises, pp. 268-291.

[3] R. H. Gray, "Business ethics and organizational change," Leadership and Organizational Development Journal, vol. 11, no. 3, pp. 12-21, 1990.

[4] P. H. Appleby, "Morality and administration," Baton Rough, $3^{\text {rd }}$ Edition, Louisiana State University Press, pp. 482-484.

[5] Time Magaine. (July 4, 2013). [Online]. Available: http://www.time.com/time/magazine/article.

[6] O. Azuka, "Mixing up corruption with divine blessing," Monday Punch Newspaper, pp. 6, May 13, 2013.

[7] A. O. Adebayo "Act of indiscipline among students," N. C. E dissertation, English Department, Osun State College of Education, 2004.

[8] N. Chucks, Corruption in Nigeria Exposed, $1^{\text {st }}$ Edition, Lagos, Concept Publication Limited, 2012, pp. 282, 492-494.

[9] O. Obasanjo, "Address on the occasion of the formal Signing into law of corrupt practices and other related offences act," Abuja, Nigeria, 2000 .

[10] J. Owuamanam "18 soldiers on trial for aiding Boko Haram," The Punch Newspaper, Tuesday, July 2, 2013.

[11] Ogundele et al. Challenges of ethics in Nigeria within the global context. [Online]. Available: http://www.lasu.edu.ng/.../AG.

[12] W. Sally, Oxford Advanced Learner's Dictionary of Current English, $8^{\text {th }}$ Edition, 2010, Oxford University Press, pp. 395.

[13] J. B. Wilbug, "Self - Interest and community," Journal of Business Ethics, vol. 7, pp. 453-458, 1998.

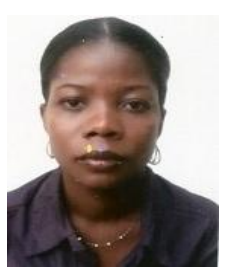

Adebayo Adeyinka O. was born in Nigeria in Gombe State in October 26, 1984. She is an erudite scholar that bagged a certificate in English/Social - Studies in Nigeria Certificate in Education [N. C. E] at Osun State College of Education, Ila Orangun, Osun State, Nigeria, on December 18, 2004. Also she holds a degree in Law [LL.B] at Lead City University, Ibadan, Oyo State, Nigeria, in July, 2011, so also at Lead City University where she is currently bagging her second degree in Public Administration. She had worked as a teacher - in- training in 2003 and 2004 respectively at Osogbo Grammar School at Osogbo as an english teacher. In 2010 she did her Chamber and Court Attachment at The Law Hub at Prime Solicitors in Ibadan where was a research junior counsel.

Ms. Adebayo Adeyinka O. is a certified project manager. She has her various research interests in law and public administration. 